\title{
Effect of Sodium Humate on the Content of Trace Elements in Organs of Weaned Piglets
}

\author{
Zdeněk Zralý, Bohumila Písaříková \\ Veterinary Research Institute, Brno, Czech Republic \\ Received February 13, 2009 \\ Accepted June 30, 2009
}

\begin{abstract}
The purpose of the present study was to assess the effect of a 21-day feeding of a diet with $1 \%$ inclusion of sodium humate $(\mathrm{HNa})$ on the content of trace elements (copper, zinc, selenium, manganese, cobalt) in tissues of weaned piglets, their efficiency and biochemical indicators. Significantly lower content of manganese in livers $(P<0.01)$ and kidneys $(P<0.05)$ was detected in piglets fed the $1 \% \mathrm{HNa}$ supplemented diet in comparison with control, non-treated animals. The concentrations of selenium in blood serum $(P<0.05)$ and muscular tissue $(P<0.01)$ were significantly lower in experimental animals. Significantly higher daily body weight gain was detected in experimental piglets compared to control animals $(0.303 \mathrm{vs} .0 .258 \mathrm{~kg}, P<0.05)$ and the feed conversion rate was increased by $6.4 \%(1.60 \mathrm{vs} .1 .71 \mathrm{~kg})$. Increased concentrations of blood serum glucose, triacylglycerols $(P<0.01)$, calcium and iron $(P<0.05)$ were detected in experimental vs. control piglets. The results of the present study indicated that despite a positive effect, sodium humate caused a decrease in concentration of physiologically important manganese and selenium in the tissues.
\end{abstract}

Adsorbents, additives, liver, kidney, muscle tissue, selenium, manganese

Good quality feeds and rational nutrition are essential preconditions for obtaining high producing healthy animals and economic prosperity in a herd. The issues associated with the food chain protection and guarantee of food safety assurance require a steadily increased attention concentrated on the investigation of effective substances that might mitigate the adverse effects of xenobiotics in the organisms of food animals. Due to the above mentioned facts, animal diets are supplemented with different types of additives including adsorbents.

Humic substances are major constituents of soil organic matter. They can be found in potable and ocean water and are a natural component of the food chain. The major components of humic compounds are humic acids (HA), fulvic acids and ulmic acids that are essential for plant growth (Stevenson 1994). HA have a tridimensional reticulate structure and contain multiple functional groups such as hydroxyl, carboxylic, carbonyl, amino, amido and sulphhydryl groups (MacCarthy 2001). Due to different HA structures, the content of functional groups and various qualities (colloidal, spectral, electrochemical and ion exchange) their considerable adsorption capacity is assumed (Klocking 1994; Alvarez Puebla et al. 2005).

Due to the colloidal characteristics and the ability to form chelates, HA and their salts can significantly modify the toxic effects of a number of xenobiotics and undesirable substances that enter the digestive tract together with feeds and water (Livens 1991). They have strong affinity for mutagens (Cozzi et al. 1993), pesticides (Negre et al. 2001; Li et al. 2003), monoaromatic and polycyclic aromatic compounds (Nanny and Maza 2001; Kollist Siigur et al. 2001), heavy metals (Livens 1991; Madronova et al. 2001; Hammock et al. 2003; Herzig et al. 2007; Zralý et al. 2008), aflatoxin B1 (Van Rensburg et al. 2006) and microorganisms (Fein et al. 1999). Positive effects of oxihumolite resulting in a decreased ammonia emission in the inside environment of broiler and pig housing were noted by Suchý et al. (1999) and Herzig et al. (2001).

Address for correspondence:

MVDr. Zdeněk Zralý, CSc.

Veterinary Research Institute

Hudcova 70, 62100 Brno, Czech Republic
Phone +420533331612

Fax +420 541211229

E-mail: zraly@vri.cz

http://www.vfu.cz/acta-vet/actavet.htm 
Furthermore, Ji et al. (2006) found reduced ammonia emission from the environment of market pigs after supplementation of the diet with humic compounds.

In the past, humic substances were studied above all owing to their positive effect on the animal organism. After feeding sodium humate to calves, Griban (1988) found an increased body weight gain and decreased mortality; after feeding the same product to dairy cows, decreased occurrence of mastitis and milk somatic cell counts were detected. Antiflogistic, antitoxic, antibacterial and antiviral effects were documented for humic acids; these can be used for therapy and prevention (Lenk and Benda 1989; Klocking 1994). Mechanism of adaptation and bioregulation properties of HA and their salts consist, besides others, in their direct effect on the immune responses, detoxicating activity of liver and sulphhydryl-disulphide balance in metabolism of proteins and saccharides (Lind and Glynn 1999; Santos et al. 2004).

Due to the fact that no toxic, allergic, mutagenic and teratogenic effects of the HA were found, HA and its sodium salt ( $\mathrm{HNa}$ ) were allowed for oral treatment of all food animals (EMEA 1999). They have been applied in horses, ruminants, pigs and poultry for treatment of diarrhoea, dyspepsia and poisoning. Despite the above mentioned positive adsorption effects, their possible adverse effect on the levels of essential nutrients - above all trace elements, which play an important role in a series of physiological functions - have been discussed.

The aim of the present experiment was to test the effect of sodium humate feeding on the content of trace elements in the organs of weaned piglets, their growth efficiency and biochemical indicators.

\section{Materials and Methods}

Twenty hybrid Pietrain $\times$ (Large White $\times$ Landrace $\times$ Duroc) pigs in equal numbers of barrows and gilts at the age of 28 days were used in the study. The experiment was performed under good hygienic conditions of accredited animal facilities in the Veterinary Research Institute. The animals were allocated to two groups based on individual live body weight and sex. The average live body weight of control (C) and experimental $(\mathrm{HNa})$ piglets was $7.95 \pm 0.87 \mathrm{~kg}(\mathrm{~V} \%=10.9)$ and $8.55 \pm 0.90 \mathrm{~kg}(\mathrm{~V} \%=10.5)$, respectively. In the course of the experiment (21 days) pigs were housed in pens, fed ad libitum the diet for early weaned piglets twice a day at 7:00 and 16:00 h. They had free access to feed and water (supplied through nipple drinkers). The control group diet contained $85.7 \%$ of dry matter with the following nutrients: $204.2 \mathrm{~g}$ crude protein $(\mathrm{N} \times 6.25), 14.3 \mathrm{~g}$ lysine, $4.9 \mathrm{~g}$ methionine, $9.2 \mathrm{~g}$ threonine, $35.0 \mathrm{~g}$ lipids, $31.9 \mathrm{~g}$ fibre, $52.6 \mathrm{~g}$ ashes, $9.2 \mathrm{~g} \mathrm{Ca}, 4.9 \mathrm{~g} \mathrm{P}, 2.2 \mathrm{~g} \mathrm{Na} / \mathrm{kg}$ and the content of metabolizable energy (MEp) was $13.2 \mathrm{MJ} / \mathrm{kg}$. All the experimental animals were fed the same diet in which $1 \%$ of the wheat content was replaced by HNa (JV 24) provided by Research Institute of Inorganic Chemistry (Ústí nad Labem, Czech Republic). The chemical analysis (mass \%) revelaed $77.80 \%$ dry matter, $27.21 \%$ ash in dry matter, $72.79 \%$ humic substances (HS) in dry matter. The concentrations of trace elements in dry matter (X-ray fluorescent analysis - RFA) were as follows: $22 \mathrm{mg} \mathrm{Cu}, 22 \mathrm{mg} \mathrm{Zn},<1 \mathrm{mg} \mathrm{Se}, 25 \mathrm{mg} \mathrm{Mn}$ and $21 \mathrm{mg} \mathrm{Co} /$ $\mathrm{kg}$. Supplementation of the diet for experimental animals with $1 \%$ inclusion of HNa did not significantly alter the content of essential nutrients. Feed consumption was recorded in each group.

Throughout the experiment the health state was monitored. Samples taken from the dead piglet were examined using bacteriological methods according to Alexa et al. (1997).

At the end of the trial, the weight of the animals was taken and blood samples were drawn from v. cava cranialis for biochemical analysis. The live body weight gains (BWG) of each animal and average weight of respective groups were the differences between the live body weight detected at the beginning and the end of the experiment. Feed conversion rate (FCR) was calculated from the efficiency of pigs in converting feed mass into increased body mass. After slaughter, liver, kidney and muscle tissue samples (m. longissimus lumborum et thoracis) were collected for detection of trace element content.

The content of dry matter, crude protein $(\mathrm{N} \times 6.25)$, lipids, crude fibre and ash in the diet were analyzed by methods AOAC (2001).

Total protein, albumin, glucose, triacylglycerols, cholesterol, alkaline phosphatase (ALP), aspartate and alanine aminotransferases (AST, ALT), calcium, phosphorus and magnesium blood serum concentrations were detected spectrophotometrically using Bio-La-Tests (PLIVA - Lachema Brno, Ltd., Czech Republic).

$\mathrm{The} \mathrm{Cu}, \mathrm{Zn}, \mathrm{Mn}$, and $\mathrm{Co}$ concentrations in the feed mixture, organs and tissues were detected using the validated method F-AAS in a Perkin Elmer Model 2100 spectrometer with the following detection limits (mg/kg): 0.03 , $0.02,0.07$ and 0.04 , respectively, and wave lengths $(\mathrm{nm}): 324.8,217.0,279.5$ and 240.7 , respectively. The amount of samples taken into analysis was 5-10 g; mineralization occurred via decomposition in dry air $\left(450 \pm 20^{\circ} \mathrm{C}\right)$. The Se concentration was assessed by a hydride generation method (HG-AAS) using AAnalyst-300 + Fias 400 
(Perkin Elmer) spectrometer at the sensitivity of $0.005 \mathrm{mg} / \mathrm{kg}$; the wave length was $196.0 \mathrm{~nm}$. The amount of $0.5-$ $1 \mathrm{~g}$ was taken into analysis, mineralization occurred via reduction of $\mathrm{Se}^{6+} \rightarrow \mathrm{Se}^{4+}$ performed by addition of $\mathrm{HCl}$. The reliability of the analysis was checked using the certified reference material Milk Powder (BCR-151 ${ }^{\circledR}$, in the case of Co, Bovine Liver-1577 ${ }^{\circledR}$, Belgium). Each sample was analyzed in duplicates.

The results were processed by statistical and graphic software STAT Plus (VRI, Brno, Czech Republic). Data were analysed using basic statistical characteristics; the mean differences were tested by $t$-test.

\section{Results and Discussion}

Experimental diet with the inclusion of $\mathrm{HNa}$ contained the following trace elements: $166.0 \mathrm{mg} \mathrm{Cu}, 203.1 \mathrm{mg} \mathrm{Zn,} 104.5 \mathrm{mg} \mathrm{Mn}, 0.378 \mathrm{mg}$ Se and $0.61 \mathrm{mg} \mathrm{Co} / \mathrm{kg}$. Control diet contained the same amounts of trace elements. The content of the investigated trace elements was in accordance with the recommended supply for weaned piglets ( $\breve{S i m e c ̌ e k ~ e t ~}$ al. 2000); the content of iron and cobalt were at the upper and lower range of recommended amounts, respectively.

The trace elements found in blood, liver, kidney and muscles of the control animals reflected the current level of dietary mineral supply to the piglets. The between-group differences in copper, zinc and cobalt content in all investigated tissues were non-significant. In experimental vs. control group, significantly lower content of manganese in liver (2.04 \pm 0.07 vs. $2.33 \pm 0.13 \mathrm{mg} / \mathrm{kg}, P<0.01)$ and kidney $(0.82 \pm 0.03$ vs. $0.87 \pm 0.03 \mathrm{mg} / \mathrm{kg}$, $P<0.05$ ) was found (Table 1). Significant reduction of selenium content in the investigated tissues and organs of experimental animals was confirmed by blood $(P<0.05)$ and muscle $(P<0.01)$ analyses.

Table 1. Trace elements in blood serum and organs of piglets after feeding sodium humate (mg/kg)

\begin{tabular}{|c|c|c|c|c|c|c|c|c|c|}
\hline \multirow{2}{*}{\multicolumn{2}{|c|}{ Indicator }} & \multicolumn{2}{|c|}{ Blood serum } & \multicolumn{2}{|c|}{ Liver } & \multicolumn{2}{|c|}{ Kidneys } & \multicolumn{2}{|c|}{ Muscle tissue } \\
\hline & & $\mathrm{C}$ & $\mathrm{HNa}$ & $\mathrm{C}$ & $\mathrm{HNa}$ & $\mathrm{C}$ & $\mathrm{HNa}$ & $\mathrm{C}$ & $\mathrm{HNa}$ \\
\hline \multirow{2}{*}{$\mathrm{Cu}$} & $\mathrm{x}$ & 1.53 & 1.55 & 23.10 & 20.50 & 4.96 & 4.91 & 0.96 & 1.01 \\
\hline & SD & 0.11 & 0.16 & 7.69 & 5.85 & 0.46 & 0.65 & 0.13 & 0.08 \\
\hline \multirow{2}{*}{$\mathrm{Zn}$} & $\mathrm{x}$ & 1.94 & 1.88 & 69.60 & 63.70 & 16.70 & 16.50 & 12.30 & 12.30 \\
\hline & SD & 0.13 & 0.13 & 12.80 & 21.00 & 1.00 & 1.45 & 0.79 & 0.71 \\
\hline \multirow{2}{*}{$\mathrm{Se}$} & $\mathrm{x}$ & $0.124^{\mathrm{a}}$ & $0.117^{b}$ & 0.310 & 0.240 & 0.710 & 0.660 & $0.078^{\mathrm{A}}$ & $0.045^{\mathrm{B}}$ \\
\hline & $\mathrm{SD}$ & 0.005 & 0.004 & 0.030 & 0.070 & 0.060 & 0.060 & 0.012 & 0.006 \\
\hline \multirow{2}{*}{$\mathrm{Mn}$} & $\mathrm{x}$ & $<0.07$ & $<0.07$ & $2.33^{\mathrm{A}}$ & $2.04^{\mathrm{B}}$ & $0.87^{\mathrm{a}}$ & $0.82^{\mathrm{b}}$ & 0.16 & 0.14 \\
\hline & SD & & & 0.13 & 0.09 & 0.03 & 0.03 & 0.04 & 0.04 \\
\hline \multirow{2}{*}{$\mathrm{Co}$} & $\mathrm{x}$ & 0.05 & 0.05 & $<0.04$ & $<0.04$ & $<0.04$ & $<0.04$ & $<0.04$ & $<0.04$ \\
\hline & $\mathrm{SD}$ & 0.01 & 0.01 & & & & & & \\
\hline
\end{tabular}

A, B significant differences at $P<0.01 ;{ }^{\text {a, b }}$ significant differences at $P<0.05$

Considering the use of adsorbents and investigating new feed supplements for farm animals, the authors discussed the hypothesis of potential adsorption of biologically important substances, such as trace elements, followed by a decrease in their biological availability for animal organisms. The obtained results confirmed that feeding $\mathrm{HNa}$ to animals had no significant adverse effect on the copper, zinc and cobalt content in the investigated organs and tissues; this finding was in agreement with Doyle and Spaulding (1978), Kirchgessner et al. (1994) and Jorhem et al. (1996). On the other hand, elevated concentrations of trace elements in pig tissues were reported by Lopez-Alonso et al. (2007). The content of copper in muscular tissues detected in the present study was higher in comparison with data presented by Lombardi-Boccia et al. (2005). The detected trace element levels in blood serum reflected the current level of dietary mineral supply to the animals and were consistent with the finding of Stowe et al. (1992), Kim and Mahan (2001) and others. The highest content of trace elements, except selenium, was detected in the liver which is a depot organ of a higher 
diagnostic value than muscular tissue for the assessment of dietary mineral supply to the animals. Kidneys, where highest concentrations of selenium were detected in the present study, are the most important organ involved in selenium disposition (LopezAlonso et al. 2007).

Owing to sodium humate feeding, the levels of manganese and above all selenium (which is physiologically important) in blood serum and muscular tissue was significantly decreased. The presented results showed that the effect of humic substances from a diet on different trace elements was unequal. Potential antagonistic interactions, such as between iron and manganese or iron, copper and zinc etc should also be taken into consideration (Creech et al. 2004). A high proportion of humic acids in water was associated with increased prevalence of thyroid dysfunctions in human population (Huang et al. 1994). The availability of selenium was impaired due to its inhibition by humic substances present in drinking water (Wang et al. 1992). Humic substances can form complexes between humic acid and heavy metal ions and also between humic acid and metal ions: $\mathrm{Zn}, \mathrm{Cu}$, $\mathrm{Mn}, \mathrm{Au}, \mathrm{Fe}, \mathrm{Al}$, and Se and thus affect their availability to the animal organism (Livens 1991). From this aspect, physiological effects of complexes prepared from humic acids and targeted biogenic elements could be tested.

The average body weight gain detected over the whole experimental period in control and experimental animals was $5.41 \pm 0.76 \mathrm{~kg}$ and $6.36 \pm 0.95 \mathrm{~kg}$, respectively (Table 2). It is in accordance with the $\mathrm{HNa}$ effect on the average daily body weight gain, which was 0.303 \pm 0.04 vs. $0.258 \pm 0.03(P<0.05)$ in experimental and control group. The average daily feed intake was higher in the experimental $(0.48 \mathrm{~kg})$ compared to control group $(0.44 \mathrm{~kg})$. A favourable effect of $\mathrm{HNa}$ treatment on the feed conversion was noted; it was improved by $6.4 \%$ in the experimental group (1.60 vs. $1.71 \mathrm{~kg} / \mathrm{kg}$ body weight gain).

Table 2. Indicators of growth efficiency in piglets fed a diet with the inclusion of $1 \% \mathrm{HNa}(\mathrm{x} \pm \mathrm{SD})$

\begin{tabular}{|l|c|c|c|}
\hline Indicator & $\mathrm{C}$ & $\mathrm{HNa}$ & Index $(\%)$ \\
\hline Number of piglets & $10 / 9^{*}$ & 10 & 107.5 \\
\hline Average live body weight D0 $(\mathrm{kg})$ & $7.95 \pm 0.87$ & $8.55 \pm 0.90$ & 111.6 \\
\hline Average live body weight D21 $(\mathrm{kg})$ & $13.36 \pm 1.06$ & $14.91 \pm 1.70$ & 111.8 \\
\hline Average live body weight gain $(\mathrm{kg} /$ day) & $0.258 \pm 0.03^{\mathrm{a}}$ & $0.303 \pm 0.04^{\mathrm{b}}$ & 93.6 \\
\hline Feed conversion $(\mathrm{kg} / \mathrm{kg})$ & 1.71 & 1.60 & \\
\hline
\end{tabular}

*one piglet dead

${ }^{\mathrm{a}, \mathrm{b}}$ significant differences $(P<0.05)$

A positive effect of humic substances in diet or water for poultry on the growth descriptors was observed by Bailey et al. (1996), Islam et al. (2005), Demeterova and Mariscakova (2006). Our results are in accordance with the study of Slavík (1999). Verifying the effects of $0.6 \%$ inclusion of humic acids in the feed for piglets, they found a decreased feed conversion by 1.27 to $5.26 \%$ and increased daily body weight gain by 2.19 to $9.42 \%$. On the other hand, Schuhmacher and Gropp (2000) found a non-significant effect of HS treatment of weaned piglets. The positive effect of humic substances can be explained by enhancement of the metabolic activity of cell membranes by acceleration of oxidative processes that due to increased nutrient uptake stimulate the vital functions (Islam et al. 2005).

One piglet with clinical symptoms of acute gastroenteritis died during the experiment. Infection with enterotoxigenic $E$. coli infection was diagnosed in the piglet. Except for this case, no clinical signs of a disease were observed in the piglets. It was confirmed by biochemical test results presented in Table 3. Significantly increased glucose and triacylglycerol levels $(P<0.01)$ as well as Ca metabolism $(P<0.05)$ were detected in experimental animals. 
Table 3. Selected biochemical indicators in the blood serum of piglets $(x \pm S D ; n=9)$

\begin{tabular}{|l|c|c|c|}
\hline Indicator & & $\mathrm{C}$ & $\mathrm{HNa}$ \\
\hline Total protein & $\mathrm{g} / \mathrm{l}$ & $51.80 \pm 5.60$ & $52.40 \pm 7.30$ \\
\hline Albumin & $\mathrm{g} / \mathrm{l}$ & $27.20 \pm 2.95$ & $27.30 \pm 3.80$ \\
\hline Glucose & $\mathrm{mmol} / 1$ & $4.67 \pm 0.53^{\mathrm{A}}$ & $5.60 \pm 0.56^{\mathrm{B}}$ \\
\hline Triacylglycerols & $\mathrm{mmol} / 1$ & $0.44 \pm 0.10^{\mathrm{A}}$ & $0.62 \pm 0.13^{\mathrm{B}}$ \\
\hline Cholesterol & $\mathrm{mmol} / 1$ & $1.63 \pm 0.30$ & $1.61 \pm 0.27$ \\
\hline ALT & $\mu \mathrm{kat} / \mathrm{l}$ & $1.10 \pm 0.33$ & $0.90 \pm 0.22$ \\
\hline AST & $\mu \mathrm{kat} / \mathrm{l}$ & $0.89 \pm 0.31$ & $0.81 \pm 0.25$ \\
\hline ALP & $\mu \mathrm{kat} / 1$ & $4.33 \pm 1.14$ & $4.88 \pm 0.63$ \\
\hline Calcium & $\mathrm{mmol} / 1$ & $2.53 \pm 0.16^{\mathrm{a}}$ & $2.70 \pm 0.13^{\mathrm{b}}$ \\
\hline Phosphorus & $\mathrm{mmol} / 1$ & $2.86 \pm 0.22$ & $3.07 \pm 0.31$ \\
\hline Magnesium & $\mathrm{mmol} / 1$ & $1.02 \pm 0.10$ & $0.98 \pm 0.10$ \\
\hline
\end{tabular}

${ }^{\text {A, B }}$ significant differences at $P<0.01 ;{ }^{\text {a }}$ b significant differences at $P<0.05$

As indicated by clinical and biochemical tests, no adverse effects of sodium humate feeding on health of experimental animals were noted. Significantly increased glucose, triacylglycerol, and calcium gave evidence of increased energy and mineral metabolism (Kreutz and Schlikekewey 1992). Other indicators of internal environment of the animals were within the physiological range (Tlučhoř 2001).

The results of the present study show that feeding sodium humate to animals can cause a certain loss of manganese and selenium from the body. If humic substances are used in pig feeding, attention should be paid to dietary supplementation of these trace elements to the animals.

\section{Vliv huminových látek na obsah stopových prvků v orgánech a užitkovost odstavených selat}

Cílem studie bylo ověřit vliv 21 denního podávání krmné směsi suplementované $1 \%$ humátu sodného (HNa) na obsah stopových prvků (měd’, zinek, selen, mangan a kobalt) ve tkáních odstavených selat, užitkovost a biochemické ukazatele. Po aplikaci $1 \% \mathrm{HNa}$ byl zjištěn průkazně nižší obsah manganu v játrech $(P<0,01)$ a ledvinách $(P<0,05)$ vưči kontrolním, neošetřeným zvířatům. Signifikantně nižší koncentrace selenu byly prokázány v krevním séru $(P<0,05)$ a svalovině $(P<0,01)$ pokusných zvírat. U pokusných selat byl zaznamenán průkazně vyšší průměrný denní prrírůstek živé hmotnosti ve srovnání s kontrolními $(0,303$ vs. $0,258 \mathrm{~kg}, P<0,05)$ a lepší konverze krmiva o 6,4\% (1,60 vs. $1,71 \mathrm{~kg})$. U pokusných selat byly $\mathrm{v}$ krevním séru zjištěny vyšší koncentrace glukózy, triacylglycerolu $(P<0,01)$ a vápníku $(P<0,05)$ ve srovnání s kontrolními selaty. Výsledky doložily, že humát sodný, i přes pozitivní vliv, snížil koncentrace fyziologicky významného manganu a selenu ve tkáních.

\section{Acknowledgement}

This work was supported by grant MZE-0002716202 and MSMT project AdmireVet.

\section{References}

Alexa P, Rychlík I, Nejezchleb A, Hamř́k J 1997: Identification of enterotoxin producing strain of Escherichia coli by PCR and biological methods. Vet Med Czech 42: 97-100

Alvarez-Puebla RA, Goulet PJG, Garrido JJ 2005: Characterization of the porous structure of different humic fractions. Colloids Surf A Physicochem Eng Asp 256: 129-135

AOAC - Association of Official Analytical Chemists International 2001: Official Methods of Analysis. $17^{\text {th }}$ ed. AOAC Inc., Arlington, USA

Bailey CA, White KE, Domke SL 1996: Evaluation of Menefee Humate ${ }^{\mathrm{TM}}$ on the performance of broilers. Poult Sci 75: 84 (Abstr) 
Cozzi R, Nicolai M, Perticone P, Desalvia R, Spuntarelli F 1993: Desmutagenic activity of natural humic acids Inhibition of mitomycin-C and maleic hydrazide mutagenicity. Mutat Res 299: 37-44

Creech BL, Spears JW, Flowers WL, Hill GM, Lloyd KE, Armstrong TA, Engle TE 2004: Effect of dietary trace mineral concentration and source (inorganic vs. chelated) on performance, mineral status, and fecal mineral excretion in pigs from weaning through finishing. J Anim Sci 82: 2140-2147

Demeterová M, Mariščáková R 2006: The effect of probiotic and humates on some performance and metabolic variables in broiler chickens. In: Proceedings Days of Nutrition and Veterinary Dietetics VII, Kosice: pp. 198-201

Doyle JJ, Spaulding JE 1978: Toxic and essential trace elements in meat - a review. J Anim Sci 47: 398-419

EMEA 1999: Committee for veterinary medical products. Humic acids and their sodium salts. Http:/www./emea. europa.eu/pdfs/vet/mrls/055499en.pdf (accepted February 1999)

Fein JB, Boily JF, Guclu K, Kaulbach E 1999: Experimental study of humic acid adsorption onto bacteria and Al-oxide mineral surfaces. Chem Geol 162: 33-45

Griban VG, Stepchenko LM, Zhorina LV 1988: The live weight gain and disease resistence of young cattle and poultry stock as influenced by physiologically active peat preparation. In: Proc VIII Int Peat Congr, Leningrad, Rusia, pp. 45-50

Hammock D, Huang CC, Mort G, Swinehart JH 2003: The effect of humic acid on the uptake of mercury(II), cadmium(II), and zinc(II) by Chinook salmon (Oncorhynchus tshawytscha) eggs. Arch Environ Contam Toxicol 44: 83-88

Herzig I, Kozler J, Písaríková B, Fengl M, Jursa V 2001: Effects of a humine acid-based sorbent on the concentration of ammonia in broiler houses. Arch Geflugelkd 65: 246-250

Herzig I, Navrátilová M, Suchý P, Vecerek V, Totusek J 2007: Model trial investigating retention in selected tissues using broiler chicken fed cadmium and humic acid. Vet Med 52: 162-168

Huang TS, Lu FJ, Tsai CW, Chopra IJ 1994: Effect of humic acids on thyroidalfunction. J Endocrinol Invest 17: 787-791

Islam KMS, Schuhmacher A, Gropp JM 2005: Humic acid substances in animal agriculture. Pakistan J Nutr 4: 126-134

Ji F, Mcglone JJ, Kim SW 2006: Effects of dietary humic substances on pig growth performance, carcass characteristics, and ammonia emission. J Anim Sci 84: 2482-2490

Jorhem L, Sundstrom B, Engman J, Astrandyates C, Olsson I 1996: Levels of certain trace elements in beef and pork imported to Sweden. Food Addit Contam 13: 737-745

Kim YY, Mahan DC 2001: Comparative effects of high dietary levels of organic and inorganic selenium on selenium toxicity of growing-finishing pigs. J Anim Sci 79: 942-948

Kirchgessner M, Kreuzer M, Roth FX 1994: Age-dependent and sex-dependent variation in the concentration of $\mathrm{Fe}, \mathrm{Zn}, \mathrm{Cu}$ and $\mathrm{Mn}$ in defferent carcass parts and their retention in fattening pigs. Arch Anim Nutr 46: 327-337

Klocking R 1994: Humic substances as potential therapeutic. In: Senesi N, Miano TM (eds): Humic substances in the global enviromnent and implication for human health. Elsevier Science B. V., Amsterdam: 1368 p., ISBN 0-444-89593-0

Kollist-Siigur K, Nielsen T, Gron C, Hansen PE, Helweg C, Jonassen KE, Jorgensen O, Kirso U 2001: Sorption of polycyclic aromatic compounds to humic and fulvic acid HPLC column materials. J Environ Qual 30: 526-537

Kreutz B, Schlikekewey W 1992: Effects of implanted bovine calcium hydroxyapatite with humate. Arch Orthop Trauma Surg 111: 259-264

Lenk T, Benda A 1989: Peat paste - humic acid containing animal health agent for prophylaxis and treatment of calves for diarrhoea. (In German). Mh VetMed 44: 563-565

Li H, Sheng GY, Teppen BJ, Johnston CT, Boyd SA 2003: Sorption and desorption of pesticides by clay minerals and humic acid-clay complexes. Soil Sci Soc Am J 67: 122-131

Lind Y, Glynn AW 1999: The influence of humic substances on the absorption and distribution of cadmium in mice. Pharmacol Toxicol 84: 267-273

Livens FR 1991: Chemical-reactions of metals with humic material. Environ Pollut 70: 183-208

Lombardi-Boccia G, Lanzi S, Aguzzi A 2005: Aspects of meat quality: trace elements and B vitamins in raw and cooked meats. J Food Comp Anal 18: 39-46

Lopez-Alonso M, Miranda M, Castillo C, Hernandez J, Garcia-Vaquero M, Benedito JL 2007: Toxic and essential metals in liver, kidney and muscle of pigs at slaughter in Galicia, north-west Spain. Food Addit Contam 24: 943-954

MacCarthy P 2001: The principles of humic substances. Soil Sci 166: 738-751

Madronová L, Kozler J, Ceziková J, Novák J, János P 2001: Humic acids from coal of the North-Bohemia coal field. III. Metal-binding properties of humic acids - measurements in a column arrangement. React Funct Polym 47: 119-123

Nanny MA, Maza JP 2001: Noncovalent interactions between monoaromatic compounds and dissolved humic acids: A. deuterium NMR T-1 relaxation study. Environ Sci Technol 35: 379-384

Negre M, Schulten HR, Gennari M, Vindrola D 2001: Interaction of imidazolinone herbicides with soil humic acids. J Environ Sci Health B 36: 107-125 
Santos A, Bellin IC, Corbi PP, Cuin A, Rosa AH, Rezende MO, Rocha JC, Melnikov P 2004: Competeition between humic substances and $\alpha$-amino acid by metal species. J Braz Chem Soc 15: 437-440

Schuhmacher A, Gropp JM 2000: Effect of humic acids on health state and performance of weaners (in German). Proc Soc Nutr Physiol 9: 77

Slavík J 1999: The effect of humic acid WH 67 in nutrition of piglets (in Czech). Krmivářství 3: 32-33

Stevenson FJ 1994: Humus chemistry-genesis, composition, reactions. John Wiley \& Sons, New York, NY: $443 \mathrm{p}$.

Suchý P, Herzig I, Písaříková B 1999: The use of sorbents on the basis of humic acids to reduce ammonia levels in stable environment. Vet Med Czech 44: 331-338

Stowe HD, Eavey AJ, Granger L, Halstead S, Yamini B 1992: Selenium toxicosis in feeder pigs. J Am Vet Med Assoc 201: 292-295

Šimeček K, Zeman L, Heger J 2000: Nutrient requirement and tables of nutritional values of pig feeds (in Czech). MZLU Brno and VUUZZ Pohořelice: 125 p., ISBN 80-7157-402-3

Tlučhoř V 2001: Evaluation of biochemical parameters in veterinary medicine from the standpoint of an individual and a herd (in Czech). Krmivářství 5: 18-20, ISSN 1212-9992

Van Rensburg CJ, Van Rensburg CEJ, Van Ryssen JBJ, Casey NH, Rottinghaus GE 2006: In vitro and in vivo assessment of humic acid as an aflatoxin binder in broiler chickens. Poult Sci 85: 1576-1583

Wang W, Wang Z, Yang CH, Peng AN 1992: Humic substances and Kaschin-Beckdisease. In: Senesi N, Miano M (eds): Humic substances in the global enviroment and implication on human health. Abstracts of invited and volunteered papers. Monopoli (Bari) Italy: $359 \mathrm{p}$.

Zralý Z, Písaříková B, Trčková M, Navrátilová M 2008: Effect of humic acids on lead accumulation in chicken organs and muscles. Acta Vet Brno 77: 439-445 
